\title{
CULTURA, IDENTIDADE E INCLUSÃO SOCIAL: O LUGAR DA RELIGIÃO \\ PARA SEUS ATORES E INTERLOCUTORES
}

Joanildo A. Burity

\begin{abstract}
Resumo: Este trabalho pretende contribuir para a compreensão dos problemas envolvidos na concepção e implementação das políticas sociais em termos de como certas demandas e atores sociais específicos ali se inserem, com destaque para as organizações religiosas. O marco de referência para a análise proposta é o da constituição e ativação de uma esfera pública híbrida, formada por atores governamentais e atores da sociedade civil, articulados em redes que operam num plano local, nacional e transnacional. Explora-se a interface entre religião e políticas sociais, a partir da avaliação de pessoas envolvidas em ambos os campos, ligadas a agências governamentais ou organizações da sociedade civil, laicas e religiosas. A ordem da exposição combina uma atenção para o contexto mais amplo em que a referência religiosa se coloca e para a percepção de atores governamentais e não-governamentais sobre o lugar e o papel da referência religiosa neste campo.
\end{abstract}

Palavras-chave: Religião e Políticas Sociais; Religião e Cultura; Religião e Espaço Público; Diversidade Cultural e Políticas Sociais

Abstract: This article seeks to contribute towards understanding the problems involved in the formation and implementation of social policies as regards how certain social demands and actors are constitutive of those, with emphasis on religious organizations. The analysis is cast in terms of the creation and activation of a hybrid public sphere, formed by governmental and civil society actors, networked at the local, national and transnational levels. The interface between religion and social policies is explored on the basis of assessments offered by informants who are part of both camps, in lay and religious organizations. The argument combines attention to the broader context in which the reference to religion is placed and to the perception of governmental and nongovernmental actors on the role of religion therein.

Keywords: Religion and Social Policies; Religion and Culture; Religion and the Public Sphere; Cultural Diversity and Social Policies

A relação estreita entre democracia e um certo grau de uniformidade cultural é uma constatação tão óbvia quanto a contestabilidade deste vínculo. Tendo prevalecido classicamente uma defesa desta proximidade, o que caracteriza o debate político hoje é

O autor agradece ao CNPq pelos recursos que permitiram a realização deste trabalho.

Pesquisador titular e diretor de Pesquisas Sociais da Fundação Joaquim Nabuco. 
precisamente a contestação de que se trata de assumir a pluralidade cultural como uma consequência direta da heterogeneidade social e da inclusividade de conceitos como cidadania e direitos humanos (cf. Koenig, 1992; Inglis, 1996; Bridges, 1994; Bartolomei, 1995; Mouffe, 1992; 2000; Kymlicka, 1996; Kymlicka e Norman, 1997; Parekh, 1997). No dizer de Koenig, "[u]ma crescente diversidade cultural, no entanto, vem requerendo novos tipos de políticas democráticas, que reconheçam pretensões de identidade particularista e, ao mesmo tempo, reforcem a integração social ao sistema político nacional” (1999:2).

A uniformidade cultural nunca foi uma realidade empírica nos países ocidentais liberais ou não. Mas ela se apresentou como horizonte benigno do processo de modernização e ampliação do acesso à cidadania, até os anos 60, quando novas formas de contestação social e política foram introduzindo questões culturais na agenda pública. Desde então, o discurso universalista da inclusividade democrática foi paulatinamente se incompatibilizando com o discurso particularista da diferença cultural. Este passou a veicular a denúncia de que, sob o manto da cidadania ocultaram-se formas de subordinação e opressão em que mulheres, minorias étnico-raciais oriundas de fluxos migratórios, grupos religiosos, culturas sub-nacionais, etc., acabaram ocupando sistematicamente posições de desvantagem e inferioridade, sofrendo discriminações e violências em muito maior grau do que os membros da cultura ou etnia dominante nas respectivas sociedades (cf. Kymlicka e Norman, 1997; Premdas, 1997; Sodré, 1999).

A diferença cultural tornou-se, portanto, nos anos 80 , um problema ao discurso da cidadania na democracia, nos países centrais, e ao longo dos anos 90, em diversas outras partes do mundo - levada pelos ventos da globalização e pela derrocada dos países do socialismo real (onde um mosaico de nacionalidades jamais havia sido inteiramente fundido pela repressão nem pela "solidadariedade proletária"). Problema traduzido quer em demandas por maior consistência das pretensões inclusivas da cidadania, quer no funcionamento da diferença cultural como princípio "não-político" de limitação do poder político - como o foram o direito natural ou os direitos humanos, no século XVIII e XIX (cf. Touraine, 1994:345, 347; Burity, 1997; 1999; 2002).

Torna-se um problema advogar a supressão da diferença cultural como garantia de estabilidade e coesão social e unidade política, idéia oriunda da rejeição iluminista aos particularismos como expressões de valores arbitrários e autoritários de comunidades encerradas na tradição. Inverte-se a lógica, para postular a garantia da pluralidade como signo de uma democracia afinada aos desafios contemporâneos de combinar a igualdade com a diferença. A identidade coletiva definida pela filiação cultural legitima-se como 
ingrediente da política democrática, embora tenha também continuado a ser falsificada (no sentido popperiano) pela irrupção de conflitos étnicos praticamente por toda parte.

A experiência contemporânea da democracia, portanto, tem que haver-se com a compatibilização - ou a tentativa de desativação/neutralização - de demandas oriundas de formas de pertencimento fundadas em atributos culturais, como origem étnico-racial, condição de gênero, filiação religiosa, pertença a determinadas tradições regionais, etc., com os dispositivos universalistas (e, portanto, supostamente neutros do ponto de vista cultural) da cidadania democrática (cf. Mouffe, 1992; 1996; Touraine, 1997).

No plano mais geral da formação da identidade democrática, este alargamento desejável ou não, dependendo da posição que se tenha frente ao estatuto da distintividade cultural - representa a valorização da dimensão simbólica das práticas sociais como componente indispensável da análise sociológica e política. Pois, embora as diferenças culturais ameacem a todo momento explodir o esforço de inclusão e coordenação da democracia liberal, analistas reconhecem hoje que a uniformidade e exigências de coesão da cultura política herdada da formação dos estados nacionais do século passado ou das disputas ideológicas do pós-segunda guerra mundial se tornaram incompatíveis com as aspirações de liberdade e justiça de muitos atores sociais.

Há, enfim, uma politização da cultura, na medida em que ela adentra a esfera pública (ou constitui novas esferas públicas), que contrasta com a resistência da cultura à crescente intervenção estatal sobre aspectos da vida cotidiana. O que pode ser compreendido como uma ampliação da disputa política na sociedade contemporânea para além da referência estatal, e mesmo em contradição com ela (uma espécie de "anarquismo" difuso), na qual elementos anteriormente contidos na esfera privada vêm a público e lógicas distintas da racionalidade política tradicional se imiscuem com esta. Cultura e democracia se articulam de forma contenciosa, recolocando o problema original do lugar da particularidade no universalismo democrático.

Nos últimos anos, discursos internacionais e paulatinamente contrapartes nacionais e sub-nacionais sinalizaram cada vez mais para a importância da cultura nas políticas estatais ou na mobilização social. Seja num sentido utilitarista, voltado para assegurar eficácia ou resultados consistentes a programas e ações governamentais; seja num sentido politizante, de reconhecimento da pluralidade, da diferença e suas bases culturais, tem havido repetidos esforços para introduzir um elemento de "awareness" ou demandas por participação ou autonomia oriundos de identidades culturais diversas. Conhecer quem são, como pensam e 
qual a história específica das "comunidades" alvo de ações educativas, de saúde, de enfrentamento da pobreza, da violência, de organização de formas de produção alternativas, etc. passa a ser um componente essencial da atuação do estado e de organizações civis "externas" a tais comunidades. Um fator de especial relevo no caso brasileiro (mas de forma alguma exclusivo dele) é o da pluralização da identidade religiosa, com desdobramentos no cotidiano das comunidades e na política, acelerando processos de mudança nesses planos para os quais os atores tradicionais estavam pouco preparados para compreender e interagir ${ }^{1}$.

Isto pode ser encontrado, por exemplo, no Relatório do Desenvolvimento Humano do PNUD de 2004, Liberdade cultural no mundo diverso de hoje (cf. Programa das Nações Unidas para o Desenvolvimento, 2004), com sua ampla discussão sobre cultura, desenvolvimento, globalização e democratização; numa maior importância conferida às políticas culturais como reguladoras não apenas de tradições e práticas comunitárias, mas de lucrativas indústrias culturais e criativas, e como indutoras de estratégias de inclusão social²; nas discussões em torno da "exceção cultural" na Organização Mundial do Comércio - em que, a partir de uma posição francesa, se buscou resguardar a produção cultural dos países das regras da livre concorrência de mercado, em nome da preservação da identidade nacional e das tradições culturais de cada país ${ }^{3}$; na criação, em 2005, da Coalizão Brasileira pela Diversidade Cultural, somando-se a uma iniciativa internacional em torno da aprovação da Convenção da Unesco sobre diversidade cultural, aprovada naquele ano e ratificada pelo Brasil em 2007 (cf. Unesco Brasilia Office, 2005).

Um lugar em que o conjunto destas "questões culturais" se manifesta fortemente é o das políticas sociais, especialmente aquelas ações que hoje assumem a ligação - confirmada por diversos estudos e estatísticas - entre a privação material ou a inserção marginal e subordinada à cidadania, de um lado, e a identidade cultural local, de outro. A demanda por

\footnotetext{
1 Para análises que situam essa emergência pública da religião num contexto global, cf. Castells, 1997; Casanova, 2001; Haynes, 2001. Uma apreciação adicional dos dados da pesquisa que deu origem ao presente texto pode ser encontrada em Burity, 2008.

2 Basta ver a linha assumida pelo Ministério da Cultura brasileiro a partir de 2003, para se ter uma clara idéia desta tendência (cf. www.minc.gov.br).

3 O Brasil interveio nesta discussão, em 2001 (ano em que a Unesco aprovou por unanimidade a Declaração Universal sobre a Diversidade Cultural), propondo uma posição intermediária entre a França e os Estados Unidos (que defendiam a plena aplicação da lógica do mercado aos bens culturais), fazendo a defesa da diversidade cultural em cada país ao mesmo tempo em que recusava a "exceção cultural" francesa, postulando a importância do livre acesso de cada povo à pluralidade de culturas dos demais povos - razão por que aceitava que a OMC fosse um fórum de definição de regras a este respeito - e o direito de cada país de promover sua própria cultura, definindo regras de proteção e subsídios específicos - razão por que faria sentido, no entendimento da política externa brasileira, defender a diversidade cultural da liberalização imediata e indiscriminada proposta pelos americanos (cf. Senna, 2006).
} 
políticas sociais/públicas sensíveis à "cultura local" ou à diferença cultural associada a gênero, raça/etnia, religião, e outras formas de identificação coletiva ou de delimitação de grupos sociais estigmatizados ou vulneráveis em razão de suas formas ou estilos de vida, supõe que o isolamento, a privação material, ou o descompasso entre grupos sociais e o ritmo da modernização hegemônica, são fatores que conduzem ao surgimento de comunidades que, para além de sua base étnica e de classe, apresentam características comuns. A não-observância desta "cultura local", destes laços comunitários, via de regra representadas por práticas e valores "tradicionais", discrepantes das culturas mais "avançadas", associadas à sociedade nacional ou ao estado, é apontada como uma das razões do fracasso de políticas sociais desenhadas para enfrentar a pobreza e a exclusão.

$\mathrm{Na}$ literatura sobre cidadania e políticas sociais há um incipiente corpo de trabalhos que procuram por em perspectiva analítica as experiências de combinação entre identidade/cultura e cidadania e o impacto que demandas por reconhecimento e respeito às diferenças têm sobre as novas condições de desenho e implementação das políticas públicas. Mas pouquíssimas análises socio-políticas focalizam em detalhe os desafios, implicações e arranjos concretos referentes à inclusão de temas como cultura e religião no âmbito das políticas públicas ou mesmo da sociedade civil.

Este trabalho, portanto, pretende contribuir para a compreensão destes problemas, a partir de uma análise que, referenciada em contextos locais (municipais e estaduais), leve em conta as múltiplas interações que o local hoje estabelece com outros níveis (nacional e internacional), seja quanto aos atores seja quanto às esferas de poder e às práticas envolvidas.

O marco de referência para a análise proposta é o da constituição e ativação de uma esfera pública híbrida, formada por atores governamentais e atores da sociedade civil, articulados em redes que operam num plano local, nacional e transnacional. Ela decorre de um duplo investimento realizado nos últimos anos para, de um lado, recompor as forças sociais de base desnorteadas pela vitória do neoliberalismo e da terceira via, e de outro lado, repensar a democracia como mais do que uma forma de governo e o público para além do estatal. Espaço de experimentação e de disputas hegemônicas, no qual tem se dado também uma redefinição da ação coletiva e da própria relação entre estado e sociedade cujo desfecho ainda não divisamos inteiramente. 
Partindo deste suposto, um conjunto de programas e projetos sociais foi selecionado, em três cidades brasileiras - Recife, Rio de Janeiro e Porto Alegre ${ }^{4}$ - que atendessem aos seguintes critérios: 1) sensibilidade à questão cultural (pensada em termos de "comunidade", raça, etnicidade, gênero ou religião); 2) formato de atuação em redes e parcerias; e 3) envolvimento de atores governamentais e da sociedade civil. Por meio de uma estratégia tripla de acesso - contatos preliminares, por meio de uma curta sondagem; envio ou aplicação de questionários; e realização de entrevistas em painel - além de levantamentos de fontes escritas (impressas ou eletrônicas/digitais), procuramos identificar pontos de contato, diferenças significativas e especificidades destas experiências, de modo a "cercar" o fenômeno de várias formas.

A estratégia de pesquisa foi fundamentalmente qualitativa, voltada a captar as articulações entre cultura e cidadania, construção institucional e implementação das políticas públicas, atores governamentais e não-governamentais, relações de mercado e relações de solidariedade. Portanto, preocupações referentes à proporção das ações que incorporam a variável "cultura", sua abrangência espacial e volume de recursos alocados, por exemplo, não foram marcantes na análise. Cremos que são importantes e podem prover mais do que referências contextualizadoras, mas demandariam procedimentos que não permitiriam o exercício de construção analítica "oblíqua" aqui proposto. Este caráter oblíquo se explica pela necessidade de uma interrogação que, a despeito das evidências apontadas introdutoriamente até aqui, permanece envolta numa malha de imagens, argumentos e infinitas ações pragmáticas de governos e organizações sociais, onde muitas vezes a enunciação de certos significantes-chave (dentre eles, cultura, participação, redes, políticas públicas, cidadania, democracia, etc.) é feita como se fossem auto-evidentes e auto-explicativos. E isto merece questionamentos.

No que segue, me aterei apenas à interface identificada entre religião e políticas sociais, a partir da avaliação de pessoas envolvidas em ambos os campos, ligadas a agências governamentais ou organizações da sociedade civil, laicas e religiosas ${ }^{5}$. Tal destaque se justifica de várias formas: a) é possível identificar uma crescente presença pública das religiões (no plural) no país das últimas duas décadas, não só resultante de processos eleitorais, mas também de uma atuação mais marcada no campo da assistência social

4 Selecionadas em função da combinação dos seguintes critérios: diversidade regional (Nordeste, Sudeste e Sul); diferenças de representação partidária nos governos municipais, estaduais e federal, no período de 2003 a 2006 (oposição em PE e RJ, situação no RS); experiências de relação entre estado e sociedade civil (alinhamento relativo no RS, oposição em PE e RJ); e características específicas do contexto local.

5 Para uma análise mais abrangente, refiro o(a) leitor(a) ao relatório final da pesquisa na qual a presente discussão encontra seu contexto (Burity, 2007). 
(entidades caritativas ou projetos sociais mantidos por igrejas, centros espíritas ou terreiros de candomblé) e da ação não-governamental (ou seja, no formato “ONG”); b) a mudança demográfica no campo religioso, com intenso trânsito e perda de espaço relativo do catolicismo, têm produzido efeitos em termos da visibilidade pública de novas identidades religiosas; c) diferenças significativas no interior do campo religioso, refletindo o impacto dos dois aspectos anteriores, ressaltam o interesse em tomar a religião como um caso particular dos processos aludidos, que não apresenta apenas especificidades, mas atesta a transversalidade das questões abordadas na pesquisa cujos resultados são aqui parcialmente expostos.

A ordem da exposição não será sistemática. Ela combinará uma atenção para o contexto mais amplo em que a referência religiosa se coloca - o de políticas e ações sociais em que o elemento estatal nunca está inteiramente ausente - e para as formas pelas quais a percepção de atores governamentais e não-governamentais sobre o lugar e o papel da referência religiosa joga neste campo. Por outro lado, as organizações religiosas pesquisadas se vêem e são vistas como parte da sociedade civil, o que exige que também as tratemos de acordo com este contexto mais abrangente. Assim, se em alguns momentos parecerá não estarmos de fato lidando com a questão da religião, mas com questões gerais sobre cultura, ou sobre as lógicas estatal e da sociedade civil, entendemos se tratar de uma necessidade analítica incontornável para compreender os novos lugares em que a questão da religião se coloca na presente conjuntura.

\section{CULTURA E RELIGIÃO NO DISCURSO ESTATAL}

São várias as iniciativas estatais no sentido de incorporar a dimensão cultural, de forma mais instrumental ou respondendo a demandas coletivas de grupos e movimentos da sociedade. Somente para citar espaços pesquisados em que alguma preocupação com o tema se colocou em cada cidade: em Recife, o Programa Multicultural da Secretaria de Cultura, o Orçamento Participativo ${ }^{6}$ e a Coordenadoria da Mulher; no Rio de Janeiro, o Programa Cheque Cidadão; em Porto Alegre, as secretarias municipais de Educação, da Cultura e de Direitos Humanos e Segurança Urbana, e a Fundação de Assistência Social e Cidadania (Fasc).

\footnotetext{
6 Maiores informações sobre o OP do Recife podem ser encontradas no site
} http://www.recife.pe.gov.br/op. 
Entretanto, o tom geral das entrevistas com atores não-governamentais e mesmo com vários governamentais releva o pouco interesse do estado em questões culturais. Não apenas se fala da histórica fragilidade das políticas culturais, estrito senso, mas de como ainda são incipientes e esparsas as tentativas de integração da cultura nas políticas e ações sociais. Além disso, face às experiências identificadas pela pesquisa - nas quais a cultura é um elemento de ações sociais e onde se dá a presença de atores estatais e não-estatais, aticulados em rede - há várias referências à ausência de influência estatal na compreensão da importância das questões culturais. Em Porto Alegre, representante do ministério de ação social da Igreja Metodista comentou que as iniciativas da igreja na área educacional e de creches não tiveram influência do estado e que não vê o estado muito preocupado com isso: nem a secretaria de educação, nem o CEDICA (Conselho Estadual dos Direitos da Criança e do Adolescente). Para uma representante da Cáritas, na mesma cidade, a preocupação com a cultura é identificada no âmbito federal; o que ocorre nos âmbitos estadual e municipal seria decorrência da implementação de programas federais.

Outro aspecto desta insensibilidade do estado face à dimensão cultural refere-se a sua pretensão de saber melhor, impondo seu modelo às comunidades. Uma coordenadora de programa da Agenda Social Rio fala de uma "mania de interferir na identidade" por parte da ação governamental, que chega com os projetos prontos, sem se perguntar sobre o que pensam as pessoas que vivem e as organizações que trabalham nas comunidades populares. Este ativismo estatal pode ser observado tanto numa direção de intervenção unilateral como em situações em que setores dos movimentos sociais ou sintonizados com eles ocupam espaços de decisão e implementam ações visando a enfrentar desigualdades assentadas em aspectos culturais. Tomemos um exemplo da experiência da Prefeitura de Porto Alegre, relativo à identidade negra, que cruza questões de identidade étnica com práticas religiosas. Respondendo a uma mobilização dos grupos de umbanda da cidade, solicitando apoio logístico e de divulgação à Semana da Umbanda, a prefeitura assume um lugar desde o qual reinterpreta a neutralidade do estado frente às religiões: embora não assuma a adesão à umbanda, explica o gestor do programa citado acima, "o poder público entende que é uma religião estigmatizada, que é uma religião que já sofreu todo esse estigma e a gente sabe que é um direito da população afro-brasileira ou afro-descendente, minimamente uma questão de reparação”. Assim, o estado estabelece uma distinção entre tomar partido e apoiar, atuando no segundo sentido, e mantendo-se aberto a qualquer solicitação de grupos religiosos (os luteranos, os assembleianos, 
exemplifica nosso informante), embora só se mencione o apoio ao evento promovido pela umbanda.

Neste exemplo, o protagonismo benigno do estado tem conteúdo diferente da intervenção não-dialógica, mas reforça esta marca da relação assimétrica da ação estatal. Num caso, impõe-se à comunidade um projeto concebido sem sua participação; num outro, setores subalternos conquistam, no interior do estado, espaço para lançar uma interpelação a sujeitos historicamente marginalizados e mesmo largamente "nãoconscientizados" de sua própria identidade, constituindo-os em sujeitos desde o lugar do estado - convocando-os a "se assumirem" ou protegendo suas práticas. Mas, mesmo neste caso, as noções de protagonismo e de sujeito aparecem reguladas pelo estado, que decide como e até onde atuar.

Em relação às concep̧cões de cultura e de identidade encontradas nesta ação governamental, podemos falar de duas possibilidades gerais de "enquadramento" da dimensão cultural nos projetos e programas sociais: uma incorporação instrumental das demandas culturais, que seriam redefinidas em termos de realização de ou apoio a atividades e manifestações folclóricas, artísticas e literárias, como parte supletiva das atividades realizadas nos projetos; e a abertura de espaços para o reconhecimento de identidades e demandas coletivas, estruturadas a partir de critérios de pertencimento (local, regional, étnico-racial, de gênero, religioso, etc.), na definição de políticas dirigidas à "inclusão social" dos coletivos definidos em função de tais critérios.

No caso da cultura como recurso político, estaríamos diante de processos de organização coletiva de demandas que teriam conquistado posições no âmbito da ação governamental. Aqui entraria tudo aquilo que hoje é chamado de ações afirmativas, de valorização da cultura como dimensão iniludível do desenvolvimento e da inclusão sociais, de políticas voltadas para grupos específicos definidos em termos de suas identidades (negros, mulheres, homossexuais, índios, grupos religiosos, etc.). Esta dimensão está associada a lutas sociais em nome de identidades particulares (ou de territórios que as definiriam) e se inscrevem na linguagem dos direitos (humanos ou de cidadania). Na grande maioria dos casos estudados, a principal referência aqui é às questões de igualdade racial - referidas à população afro-descendente - e de gênero. Mas há uma percepção significativa do lugar que a diferença religiosa - normalmente referida à emergência dos evangélicos pentecostais na cena pública brasileira - assume cada vez mais no encaminhamento social e político dessas demandas já citadas e outras, específicas dessas identidades religiosas. 
Atravessando e para além destas duas orientações gerais da recepção da cultura nas políticas públicas, a pluralidade de concepsões que animam estes entendimentos básicos quanto ao lugar da cultura nos programas e projetos sociais é significativa. A descrição mais recorrente nas falas dos agentes governamentais é a que associa cultura, de um lado, a tradições e costumes, normalmente enunciada como colocando o desafio da "preservação" e do "resgate"; e, de outro lado, a que associa cultura a manifestações lúdicas ou artísticoliterárias, eruditas ou populares.

Associado a estas representações convencionais do termo, surge um discurso que vê no fenômeno da exclusão social um componente cultural, sob duas formas: a da multidimensionalidade da exclusão, em razão da origem geográfica (regionalismos e localismos), da forma de ocupação do espaço urbano, da origem étnica, da orientação sexual, da pertença religiosa, etc., e, não raro, da combinação estigmatizadora de vários destes e outros atributos pessoais; ou a de práticas culturais de grupos que destoariam muito do ethos hegemônico ou se oporiam à doxa vigente na sociedade em geral. Neste caso, é possível que a marginalidade destes grupos também seja vista com desconfiança ou como uma ameaça por atores socialmente integrados ou pelas classes dirigentes. Nestes casos, fala-se de "sensibilização", "resgate" de costumes e tradições, "respeito à identidade". Este resgate é visto como condição de autonomia dos sujeitos e, de modo fortemente recorrente, como recuperaşão ou construção da auto-estima.

Como se percebe a possibilidade de interferir neste nível da identidade das pessoas assistidas? Através de atividades culturais e intelectuais programadas como parte da oferta de serviços que cada projeto ou programa fazem. Palestras; apresentações musicais e teatrais; realização de oficinas de artesanato, música, artes plásticas, etc., são programadas, com conteúdos voltados para salientar a história da exclusão ou a riqueza e beleza das tradições de onde provêm os beneficiários. Há nestas atividades uma ambivalência que se expressa na mobilização de concepções convencionais de cultura (por exemplo, como tradições pré-existentes que se procura preservar da mudança que vem pelo contato com outras, ou como valores e práticas que se teriam perdido ou esfumado em meio a uma história de negação e descaso para com as identidades dos excluídos).

A ambivalência reside na tentativa de inscrever velhos entendimentos de cultura na linguagem dos direitos e da cidadania ativa, sem a percepção de quão assimétrica é esta reconstrução da cultura do outro feita por quem, desde fora, sabe o que este outro ignoraria - saber este que seria uma condição para a emancipação (a velha questão da consciência que vem de fora). A ambivalência reside ainda na desatenção para a dimensão 
construída desta cultura que é apresentada ao outro como se fosse sua. Mesmo que as atividades permitam que os beneficiários "tragam" sua experiência e saberes para o espaço público criado pelo encontro de iguais e diferentes, assistidos e assistentes, a reelaboração da mesma se dá tanto pela sua reinscrição numa linguagem politizante - a da cidadania ativa, a da cultura como reivindicação de respeito a uma identidade social subalterna -, como pelo que é seletivamente incorporado no discurso do "resgate".

Resgatar a auto-estima, portanto, de um lado, corresponde a um ato de valorização da dignidade do outro subalterno, e de outro, a uma tomada de posição por parte deste último com base naquilo mesmo que seria sem-valor: sua linguagem, suas formas de vida, a dimensão comunitária da sua vivência cotidiana (vista como antídoto aos males do individualismo e como matéria-prima para construção de uma experiência participativa), sua cor da pele. No discurso governamental pode-se encontrar que atingir esta dimensão da auto-estima produz uma aproximação entre o estado e os cidadãos e cidadãs assistidas.

A valorização das "referências culturais, referências religiosas", afirma uma gestora da política de assistência municipal em Porto Alegre, permite "que se possa chegar mais perto dessas pessoas." Essa valorização tem dois sentidos, o de criar empatia na população em relação aos agentes estatais que com elas se relacionam na implementação das políticas sociais, e o de diminuir a distancia que a imagem do estado infunde em relação à autoimagem do cidadão pobre ou marginalizado/discriminado - distância que pode ser entendida como repulsa ao poder que vem de cima ou como alienação do estado em relação ao que é importante na dimensão do cotidiano das pessoas.

Em ambos os casos, tal aproximação simbólica facilita a aproximação física entre agentes estatais e agentes sociais, ensejando um ganho de eficácia à política em questão. Torna o estado compreensivo para com a identidade de seus cidadãos e cidadãs e suas razões de agir compreensiveis a eles/elas.

Esta estratégia não deixa de ter os seus riscos. Um deles é o de uma elaboração desde fora da cultura do outro, por parte do discurso governamental ou do discurso nãogovernamental, produzindo uma cultura para o outro, através de processos seletivos de ressaltar traços da cultura subalterna que possuiriam potencial mobilizador (quando não contestador) - caso se trate de uma ação governamental em busca de desenvolver formas ativas de participação cidadã - ou produzam efeitos de aquiescência. Neste caso, dizer ao outro qual é a sua cultura - por meio de um discurso da história referenciado pela noção de "resgate", mas que escolhe, deliberadamente ou não, o que é importante e válido nesta 
história - serve para produzir uma tomada de consciência de si dos subalternos, mas não necessariamente do que seria "objetivamente" sua cultura como fundamento de uma subjetivação autônoma.

Mas o discurso governamental não deve ser visto apenas como tacanho e manipulatório. Nas últimas duas décadas, o paulatino, porém sistemático acesso ao estado de pessoas e discursos oposicionistas à esquerda - seja por meio do processo eleitoral, seja da prática do concurso público - consolidou a figura poulantziana do estado como arena de conflitos, de disputas hegemônicas. Há muito mais do que elites retrógradas, culturalmente obtusas, nos circuitos de decisão política e de implementação técnica das ações governamentais. Isto confere certamente ambigüidade às práticas governamentais, mas não tanto por se tratar de elaborações intelectualmente heteróclitas ou mal fundamentadas, e sim por corresponder a disputas hegemônicas, micro e macro, quer baseadas na iniciativa de "militantes" anônimos atuando nos órgãos governamentais ou resultantes de mudanças de governo.

Assim, há um processo pelo qual determinadas concepções sobre a construção de subjetividades autônomas, a asserção da reivindicação de direitos, a abertura para práticas de governança que incorporam setores subalternos da sociedade, encontram lugar no discurso governamental. Isto não ocorre de forma homogênea e linear. Há diferenças, por exemplo, entre o que se dá na área de educação ou de finanças públicas, ou o que se dá na área de saúde ou de desenvolvimento econômico. Educação e saúde aparecem como campos em que o discurso contra-hegemônico encontra muito mais espaço.

O campo das políticas sociais torna-se assim um lugar estratégico para se disputar a hegemonia aos setores controlados pela lógica do capital, do mercado. Também há diferenças locais, na medida em que o acúmulo de conquistas num sentido popular ou a existência de situações de "equilíbrio catastrófico" (em que velhas forças e práticas perderam sua hegemonia, mas ainda disputam com forças emergentes que não têm a direção do processo, como dizia Gramsci) indicam graus distintos de avanço, seja nos recursos argumentativos, seja nas práticas governamentais.

A sofisticação do discurso governamental - sua sintonia com debates sobre, de um lado, as injunções da eficiência gerencial e da governança, e de outro, as questões de reconhecimento e menjo das diferenças - não deve ser pensada como mera atualização da prática governamental. Estando imerso numa multiplicidade de referências espaçotemporais e de formas e graus de desenvolvimento das relações estado-governo-sociedade 
civil, há recursos já consolidados pelo estado que continuam "à disposição" das novas forças hegemônicas, em todos os níveis federativos. Dentre estes, ressalte-se a preeminência do poder executivo e de sua rede de agências, instâncias e formas de produção de saberes sobre o social e de intervenção em pequena e grande escala.

\section{CULTURA E IDENTIDADE NAS POLÍTICAS DA SOCIEDADE CIVIL}

Outro lugar de onde se pode observar a questão da incorporação dos temas da cultura e da identidade nas políticas sociais é o da sociedade civil. Ainda que devamos nos manter alertas contra uma essencialização deste ator, que na verdade nomeia um projeto político muito mais do que descreve um conjunto de agentes e organizações sociais convergentes, não há dúvida de que, no contexto brasileiro contemporâneo, a "sociedade civil" constitui-se num campo ético-político relevante para pensar os caminhos das políticas sociais.

A "chegada" da cultura no discurso sobre as políticas públicas deve-se fundamentalmente à mudança identitária vivenciada no campo da sociedade civil, por parte de movimentos sociais e organizações não-governamentais, notadamente a partir de fins dos anos de 1980. A cena da democratização, qual uma caixa de Pandora, liberou uma miríade de formas de articulação de agravos e carências dirigidas à ordem vigente que se reconheciam na representação da democracia como único regime no qual as demandas populares, a livre expressão das diferenças e o equilíbrio da equação estado/sociedade na direção de uma socialização da política encontram seu espaço de reconhecimento assegurado. Assim, a articulação de demandas identitárias enquanto demandas sociais por igualdade e liberdade encontrarão na sociedade civil um campo fértil para sua expressão.

Mas, como no caso do estado, na seção anterior, aqui também a inserção da lógica cultural - que é uma lógica da eficácia do simbólico e da diferença na articulação do discurso democrático - é marcada pela multi-temporalidade de seu avanço e pela multiplicidade de posições discursivas construindo o que vêm a ser cultura e demandas baseadas na cultura. Devemos, portanto, explorar estas dimensões, levando em conta que foram pesquisadas entidades 
civis do tipo ONG, organizações religiosas, e ligadas a movimentos sociais, nas três cidades.

\section{Tomemos primeiramente a importância das questões na prática das} entidades ou de projetos mantidos por elas. Em Porto Alegre, encontra-se um ambivalência também identificável nos casos do Rio de Janeiro, em relação à "suficiência" da cultura. Ora se diz que as questões de cultura e identidade não são prioritárias, em contraste com as de assistência (saúde e educação), quando muito incluindo-se a realização de eventos culturais na programação dos projetos - caso das ações da Sociedade Metodista de Amparo à Infância - ora se fala numa transversalidade da questão cultural, que não receberia tratamento específico - caso da Cáritas (Regional Sul). Em ambos os casos, foi decisivo o impacto dos chamados novos movimentos sociais na sensibilização de atores mais tradicionais do campo da esquerda, laica ou religiosa.

Na Cáritas, ouvi sobre planos para há planos para realizar-se uma discussão sobre gênero, envolvendo entidades como Comissão Pastoral da Terra, Associação Cultural de Oficineiros, Centro Ecumênico de Evangelização, Capacitação e Assessoria e outras, por perceber que se trata de uma questão inadiável, colocada pela participação em "outros processos" e não por iniciativa própria da entidade. Mesmo assim, tudo seria muito incipiente, embora, "de certa forma, à medida em que a Cáritas vai discutindo essas questões, vai provocando outros setores da igreja a discutir, e também a própria igreja", diz a coordenadora da entidade.

Quando essas entidades se inserem em redes com outras organizações da sociedade civil, há um incremento da tematização de questões culturais. Os informantes da Igreja Metodista atribuem isto ao distanciamento em relação ao espaço de igreja local, permitindo maior liberdade de movimento aos militantes sociais da Igreja: "Quando a gente participa em rede a gente procura seguir essas questões culturais e identitárias, mais culturais até", a despeito de que internamente à igreja essas questões não são priorizadas. Mesmo assim, a cultura se inscreve em ações voltadas para outros fins, como o enfrentamento da drogadição entre crianças e jovens, cujo afastamento da escola lhes deixa vulneráveis ao ócio e ao envolvimento com drogas ou com o crime.

Um pastor metodista referiu-se ainda às resistências oriundas do discurso da teologia da libertação, que se tornou bastante forte na Igreja entre os anos de 1970 e 1980. Segundo ele, estavam mais claras dentro da formulação inicial da teologia da libertação as questões de classe, as questões mais estruturais, econômicas. Como decorrência da repercussão que 
se foi dando aos temas culturais, estes foram sendo somados às temáticas originais. Noutro trabalho, chamamos a atenção para a relação da crise do discurso pastoral ligado à teologia da libertação com a adoção de um olhar cultural, no contexto da retomada do conservadorismo a partir do papado, da crise de mobilização dos movimentos populares desde a segunda metade dos anos de 1980, e do crescimento evangélico (cf. Burity, 1994).

Nosso segundo foco na análise das posições das entidades da sociedade civil nesta seção concerne às concepções de cultura e identidade aí encontradas. Aqui, diferentemente da ênfase no discurso governamental, há uma predominância de entendimentos mais “antropológicos" de cultura, independente do perfil das entidades - religiosas ou laicas. Tende-se a pensar cultura a partir de uma aproximação com comunidade (local) e formas de vida. O fortalecimento do espírito comunitário é visto como muito importante para contrabalançar a cultura consumista, individualista, "resgatando" os valores de comunidade, oriundos muitas vezes do mundo rural. O resgate da cultura da comunidade quebraria o individualismo. Cultura também é vista, por exemplo, no discurso de um representante da Fundação Luterana de Diaconia ${ }^{7}$, em termos de cultura política: através dos projetos sociais apoiados pela entidade e da mobilização da comunidade que eles pressupõem, sua negociação com o poder público vai mudando a cultura de favor (clientelista) por uma de direitos e cidadania. O pequeno projeto ajuda nisso, na medida em que os próprios participantes se envolvem diretamente na sua construção.

Para a ONG Educadores da Paz, entidade atuante na promoção da cultura de paz em Porto Alegre, a questão da cultura remete à vivência cotidiana e à implicação entre o pessoal e o coletivo, como as pessoas pensam, sentem e se relacionam, sendo uma condição essencial para o trabalho de prevenção da violência e de educação para os direitos humanos. Além disso, comenta o padre que a dirige,

é um tema que mexe com a nossa subjetividade, é diferente de você trabalhar uma questão política ou social. Claro, você é atingido, mas ainda fica num âmbito exterior. Agora, a cultura, não tem como você separar você, a sua identidade pessoal, da questão cultural.

No caso dos luteranos (pesquisados através da Fundação Luterana de Diaconia, ligada à Igreja Evangélica de Confissão Luterana no Brasil [IECLB], e do ministério social da Igreja Evangélica Luterana do Brasil [IELB]), há um processo de mudança identitária em curso desde os anos de 1970, no bojo de uma transição da cultura germânica para a cultura

\footnotetext{
7 Oscip criada em 2000, vinculada à Igreja Evangélica de Confissão Luterana no Brasil, e voltada a financiar
} projetos sociais mantidos por entidades religiosas e laicas, com foco no enfrentamento da exclusão social. 
brasileira na definição da identidade religiosa do grupo. Os luteranos vêm fazendo esse ajuste de percepções culturais, pensando-se mais como "brasileiros" e vocacionados a realizar seu trabalho missionário na sociedade inclusiva. "Luterano" e "alemão" deixam de ser idênticos e a Igreja vê-se desafiada a sair do gueto étnico-cultural para participar da construção de uma sociedade brasileira, inclusive ouvindo os afro-descendentes ${ }^{8}$. Os luteranos da IECLB possuem bastante visibilidade no trabalho com povos indígenas nas regiões Sul, Centro-Oeste e Norte, ao lado da Igreja Católica, acompanhando as migrações de membros das igrejas do Sul para aquelas regiões, à medida que a fronteira agrícola do país se deslocou, durante o regime militar, naquela direção. Esta atuação gerou uma ação pastoral específica: o Conselho de Missão entre Índios (Comin), criado em 1982 ${ }^{9}$ Na raiz desta experiência esteve o Grupo de Trabalho Missionário Evangélico (GTME), criado em 1979, para coordenar ações ecumênicas de igrejas protestantes junto aos povos indígenas, influenciando o surgimento do Comin, entre os luteranos da IECLB e de entidades congêneres nas igrejas Anglicana, Metodista e Presbiteriana Independente ${ }^{10}$. Os luteranos mais conservadores, da IELB, também realizam trabalho com índios, mas não possuem uma organização específica para coordenar estas ações.

Vale a pena comentar sobre a perspectiva assumida pelo Viva Rio, que trabalha com favelas na capital carioca ${ }^{11}$. Neste caso, a cultura tampouco entrou como princípio estruturante, mas "como estratégia de trabalho". Havia uma percepção da importância, em decorrência de a ONG-movimento manter uma relação simbiótica com o Iser (Instituto Superior de Estudos da Religião), onde o foco na religião (numa perspectiva de matriz ecumênica) já representasse uma tematização da "diversidade cultural". Mas o significante mestre do Viva Rio era “cidadania”, ou seja, "participação cidadã da sociedade civil”. Desta forma, a cultura é incorporada como estratégia - ou seja, em nossa terminologia, como instrumento - para alcançar a mobilização necessária às campanhas promovidas.

8 Este processo se dá nos dois grandes ramos luteranos brasileiros: a Igreja Evangélica de Confissão Luterana no Brasil (IECLB), originada na migração direta de alemães para o sul do Brasil ainda no século 19 (1824), mantendo-se como igreja étnica por mais de cem anos, até fins dos anos de 1960; e a Igreja Evangélica Luterana do Brasil, originada de migração indireta de alemães, a partir dos Estados Unidos (sínodo de Missouri), em 1904, e que somente a partir de fins dos anos de 1980 realmente decidiu assumir-se como igreja de brasileiros, havendo ainda, segundo um de seus pastores, coordenador do ministério de ação social, ainda resistências a esta mudança de perfil.

9 Ver detalhes em http://www.comin.org.br.

10 Maiores informações, cf. http://www.gtme.org.br.

11 O Viva Rio possui um projeto específico chamado Viva Favela, que se propõe a promover a inclusão digital, a democratização da informação e a redução da desigualdade social dos moradores da favela. $\mathrm{O}$ projeto possui um site na internet (http://www.vivafavela.com.br/default.asp). Uma análise do projeto, contendo entrevistas com algumas de suas lideranças pode ser lida em Vital e Cunha, 2003. 
Por exemplo, no lançamento do Viva Rio, em 1993, foram propostos dois momentos em que a religião e a espiritualidade estiveram integradas à chamada a uma reflexão sobre a violência e a paz da cidade: a convocação para a observância de dois minutos de silêncio, para uma parada geral da cidade; e a convocação das religiões para ocuparem diferentes espaços da cidade e ali fazerem-se orações pelo Rio de Janeiro. Utilizou-se então a mesma estratégia experimentada na Conferência das Nações Unidas para o Meio Ambiente e o Desenvolvimento (Eco-92), de organizar uma vigília no Centro do Rio de Janeiro, com a presença de uma variedade de religiões, cada uma "no seu espaço próprio", segundo uma lógica ao mesmo tempo de contigüidade (e não de integração, para evitar conflitos ou esvaziamento). A idéia era explorar o simbolismo de certos espaços da cidade, associandoos a determinadas religiões. Os pentecostais realizaram um culto na praça pública da Cinelândia; o candomblé, com sua estética das vestimentas e da dança, ficou com o Museu de Arte Moderna; a umbanda ocupou a praia, com suas oferendas; a Nova Era ficou com os jardins do verde; a Igreja Católica dividiu-se entre a perspectiva da hierarquia ocupando o Cristo Redentor - e a do laicato - que fez um terço, um colar humano por vítimas da violência, em torno da estátua de São Sebastião!

Aqui estamos explicitamente diante de uma lógica da "diversidade" multicultural: um fio comum anima uma aproximação, mas esta não se dá segundo a modalidade da articulação (na qual a identidade dos sujeitos é pelo menos parcialmente alterada, originando um novo ator coletivo). As religiões são convocadas - e respondem positivamente - mas não promovem um ato conjunto. Cada uma fala sua linguagem e ocupa o seu espaço. O princípio articulatório se colocava fora deste campo, na ONGmovimento Viva Rio e no conjunto mais restrito de entidades laicas que compunha sua liderança $^{12}$.

Por outro lado, tal configuração permite-nos identificar uma outra característica de uma operação hegemônica: ela pode ser realizada a partir de diferentes lugares, e mesmo com motivações diferentes, sem perder seu efeito hegemônico. Este aspecto - que poderia ser redescrito em termos de uma estratégia de exibição ou exposição das diferenças constitutivas de um movimento social - fica ainda mais claro em algumas manifestações do movimento Reage Rio, em que se organizou uma espécie de manifestação por alas, como na evolução das escolas de samba, cada ala representando um grupo, uma identidade, e apela-se ao efeito de conjunto como expressão do "povo unido". No dizer de uma das

12 Para análises muito interessantes destas experiências, cf. Birman, 2004; Leite, 2003; 2004. 
lideranças do Viva Rio, "você tem alas que se movimentam, se apresentam, cada uma com sua história para contar, e não tem um microfone" (referindo-se à diferença em relação às manifestações de protesto dos movimentos estudantil, sindical ou de partidos de esquerda, nas décadas anteriores, em que uma pessoa se colocava frente ao microfone, enquanto as demais “assistiam”). Esta compreensão assume que a articulação das diferenças não passa por sua convergência ou fusão no curto prazo, que há uma necessidade ao mesmo tempo estratégica - dada pela urgência das demandas - e pedagógica - dada pela natureza dos atores interpelados - de vivenciar a dificuldade da convivência e da produção de consensos entre os atores participantes do movimento ou convocados por este.

A questão da instrumentalidade da cultura nas ações da sociedade civil é ao mesmo tempo imediatamente perceptível e controvertida. De um lado, é recorrente encontrar-se a realização de atividades culturais - música, dança, teatro, artes plásticas, artesanato, etc. como parte da dinâmica de projetos, e é majoritariamente neste sentido que cultura é compreendida. De outro, há em algumas entidades um amadurecimento da reflexão e da ação no sentido de tematizar questões mais abrangentes, a partir de um entendimento de seu caráter cultural (identidades de gênero, racial e idade são as mais salientes). Mas o sentido da instrumentalidade muda, e não apenas entre estes dois tipos de intervenção; também muda em função do perfil da entidade.

Assim, há duas compreensões principais da instrumentalidade: uma, em que se usa a cultura com o fim de alcançar outros objetivos, tomando-a como entretenimento, recurso de socialização dos beneficiários; e outra, em que assume-se que o recurso à cultura é uma condição indispensável para se respeitar a dignidade dos beneficiários e ganhar sua adesão para um trabalho que não deve ser feito para eles, mas com eles e, em alguns casos, por eles. Normalmente, a primeira concepção está associada a ações de caráter mais assistencial ou filantrópico. Mas ela também aparece na idéia de que a cultura é um meio facilitador na resolução de conflitos, ou na elevação da auto-estima das pessoas. A segunda concepção surge conectada a ações que integram aspectos assistenciais, mas priorizam o trabalho formativo e mobilizatório. É difícil, neste último caso - e eles estão claramente presentes em organizações mais organicamente conectadas às redes de movimentos sociais ou de organizações não-governamentais distinguir o instrumental do estratégico.

Falar em cultura como direito, ou em outro sintagma, no direito a ter cultura, é também falar da tensão entre instrumento e recurso político com relação à pluralidade, alerta uma informante do Centro de Cultura Luiz Freire, de Olinda. De um lado, para ela, a inclusão social só seria completa se todos esses direitos - econômicos, sociais, culturais - fossem 
igualmente assegurados; donde a relevância dos direitos culturais: "Sem a cultura, o sujeito não está totalmente incluído na sociedade". De outro lado, numa sociedade plural como a brasileira, há muitas culturas, e "o que é aceito em uma determinada cultura não é aceito em outra, e eu acho que é aí que está o dilema”. Nas manifestações culturais tal pluralidade é até mais aceita, é vista como testemunha do que se tem chamado de diversidade cultural. Mas mesmo aí, não se vai muito fundo na apreciação dos valores e da história subjacentes a tais manifestações; elas são apropriadas esteticamente. Tomando o exemplo do maracatu, ela ressalta, então, que não se quer ter que lidar com a perspectiva religiosa, afro-brasileira, politeísta, com a herança de resistência histórica. Em outras palavras, o desafio da vivência intercultural remete à dimensão política da cultura, que a versão celebrativa da cultura não incorpora, limitando-se ao valor estético. E a questão não é apenas de como aprender a viver junto, em face de distintas culturas; é também, como demonstra o caso dos povos indígenas, do custo de assumir elementos de outras culturas para poder sobreviver muitos índios do Nordeste perderam suas línguas de origem, por exemplo, para se manterem como índios.

\section{O LUGAR DA RELIGIÃO, DE PER SE}

Suscitar a questão da religião numa análise da apropriação da cultura e da identidade nas políticas e ações sociais promovidas por atores governamentais e não-governamentais é um gesto deliberado de marcação da diferença, agora por parte deste analista que escreve. Não há muita visibilidade do tema na literatura sobre o assunto, nem no seu sentido técnico análises das políticas sociais e das ações realizadas por organizações da sociedade civil nem no sentido do vocabulário corrente na militância social e política - os discursos em torno da inclusão social, da cidadania, da participação democrática, da justiça. Não simplesmente porque os cientistas sociais não falam sobre o assunto - este também é um dado importante. Os atores, mesmo os religiosos, nem sempre se manifestam espontaneamente sobre o assunto. Naturalmente, essa linha de raciocínio pode derivar para dois procedimentos problemáticos, e que tentei evitar: o de censurar o "silêncio" sobre a temática religiosa e o de induzir a tornar importante o que poderia ser marginal no cotidiano das ações.

Contudo, ao procurar evitar estes riscos, não posso deixar de questionar os termos que os sustentam, em nome de uma certa incitação à linguagem que teria o caráter de liberar, pela provocação de um tema-tabu, uma "psicanálise" das ações coletivas em prol da cidadania e 
da inclusão social no Brasil de hoje. De um lado, é preciso registrar o silêncio, a escassez do discurso. Ela é sintomática. Fazê-lo não precisa necessariamente levar à censura, mas antes, à colocação em discurso de processos claramente perceptíveis a um olhar atento, mas nem sempre articulados por parte de quem não se interessa pelos efeitos sociais que se expressam na dinâmica religiosa. Pois, é fato que não apenas há centenas de entidades religiosas atuando neste vasto campo da ação filantrópica, assistencial, de mobilização e organização coletiva que poderíamos genericamente chamar de campo da ação social ou das políticas sociais. Também nas entidades laicas, há um número não desprezível de pessoas que estão vinculadas a religiões e que se engajam na ação social como uma extensão de seus compromissos de fé; e há militantes anônimos nos movimentos populares e de vizinhança que, com ou sem o apoio de suas lideranças ou pares religiosos, fazem o mesmo nas lutas sociais cotidianas. Então, fazer falar essa dinâmica pode ser um exercício ilustrativo da complexidade da trama social e política das relações estado/sociedade no país.

De outro lado, incitar à linguagem ou apurar o olhar para perceber os lugares ocupados pela religião não significa tentar atribuir centralidade ao que é marginal. Novamente, é sintomático que tantas análises sobre a sociedade civil, o campo das políticas e ações sociais e as transformações da relação estado/sociedade sejam produzidas sem que nada se analise a respeito do lugar da religião - tanto a "organizada" como a "vivida"- nestes processos. Nos três contextos estudados, chega a ser óbvia a presença de iniciativas, de variados conteúdos sócio-políticos, envolvendo agentes religiosos, algumas das quais pude já apontar na análise acima.

Nesta linha, com efeito, ao se provocar a discussão, surge uma elaboração sobre a religião que já se faz no próprio registro da problemática que enquadra a presente análise. Ou seja, a religião surge como um sintoma da diferença, como duplo reconbecimento da pluralidade e do potencial conflitivo desta. Não são exatamente falas que constatam o peso da religião na sociedade brasileira, mas falas que situam a religião culturalmente a partir da experiência recente de sua pluralização no Brasil: são os evangélicos (que, na fala de um representante do Viva Rio, exemplificam uma lógica universalista, não territorializada, em meio à cultura segmentar das favelas cariocas), são os seguidores do candomblé (que, em diferentes falas, apontam para os limites da aceitação da cultura afro-brasileira mesmo na conjuntura atual de "valorização das diferenças" e "afirmação da diversidade"), são os católicos (que são vistos dentro da ambigüidade que a presença católica no Brasil encerra: fator de colonização cultural, de 
mobilização social nos tempos adversos da ditadura, de trabalho social ininterrupto ao longo da história republicana e com diferentes sentidos ideológicos e contribuições sociais).

Essa experiência da diferença é conflitiva, não somente pela afirmação que ela representa - "novos" atores buscando delimitar um lugar para si nas esferas públicas constituídas ao longo do processo recente de democratização -, mas também pela polêmica que suscitam suas formas de vida (seu vocabulário; suas práticas de mobilização de recursos humanos, materiais e simbólicos; sua recusa a regularem-se pelos cânones do padrão sincrético brasileiro - a cordialidade, a deferência, a inclusão subordinada, o transformismo - ao mesmo tempo em que recorrem a alguns traços da cultura política claramente hegemônicos - como a política do favor, a corrupção política, a cultura de mercado). A novidade, incômoda novidade, é o que se ouve e percebe, tem praticamente um só nome: evangélicos pentecostais. Mas não nos deveríamos deixar enganar pela tentativa de singularizá-la. Seria fazer o jogo dos próprios pentecostais. Há muito mais nesse iceberg (a imagem é sugerida por Rubem César Fernandes, num trabalho sobre o terceiro setor) do que pentecostais assaltando o espaço republicano.

Assim, a explicitação da variável religiosa na abordagem desses temas pretende trazer à tona o que, ainda quando retoricamente assumido - ao se incitar ao discurso, lembrando a expressão foucauldiana - não cessa de ser ocultado como relevante ao discurso público de atores governamentais e não-governamentais. "Trazer à tona" aqui significa por em evidência o tema tanto em face da literatura acadêmica quanto da reflexividade dos atores, significa propor um debate. No caso, um debate que não apenas propõe a "inclusão" de uma variável desconsiderada, mas suscita a hipótese de que ela é boa para pensar o conjunto das questões com que nos deparamos no processo de tornar a dimensão simbólica da vida social parte da ação estratégica de diferentes atores sociais. Olhar pelo prisma da religião ajuda a trazer para a discussão que diferença faz abordar a cultura - instrumentalmente ou em seu caráter antagonístico, político - no enfrentamento dos problemas da exclusão social, da pobreza, da fragilidade dos direitos, da promoção da cidadania. Portanto, trata-se de por na agenda a religião como um lugar a partir do qual essas questões podem ser pensadas e como teste da coerência das práticas de inclusão social, de reconhecimento, de explicitação das diferenças numa ordem que se quer/descobre/inventa como pluralista e democrática.

Nesta perspectiva, há constatações que sugiro deixem de ser apenas concessões aos fatos, admitidas apenas quando se é perguntado diretamente, mas para todos os efeitos práticos, fora de questão, e passem a ser parte de uma análise integrada das políticas e ações sociais 
no Brasil contemporâneo. Em outras palavras, não se pode mais ocultar que as religiões estão claramente presentes no cotidiano das comunidades populares, para além de suas atividades estritamente rituais ou de conquista de fiéis, em iniciativas assistenciais de diferentes $\operatorname{escopos}^{13}$. Não se pode deixar de perceber certas formas de intervenção religiosas que assumem proporções muito além de experiências pontuais e territorializadas, como no caso de ONGs religiosas ou organismos de pastoral católicas e evangélicas: a Cáritas, a Catholic Relief Service (CRS), as pastorais sociais da Igreja Católica, a Visão Mundial, a Diaconia, a Fundação Luterana de Diaconia operam em âmbito nacional ou regional e se inscrevem em redes de intervenção da sociedade civil conectadas em escala regional, nacional e internacional. É recorrente encontrar-se lideranças da sociedade civil que mantêm vínculos orgânicos com religiões não-católicas, no campo das organizações não-governamentais, nos movimentos populares e em algumas entidades públicas. Independentemente da representatividade estatística que tais constatações autorizem, a presente análise se coloca a relevância de tomar uma esfera específica da ação social e nela e por ela interrogar uma institucionalidade e uma cultura política dominantes. No que segue, portanto, procurarei realçar este lugar da religião, tanto no sentido dos papéis assumidos, como do espaço dispensado a ou ocupado por ela, enquanto objeto de crença ou de reconhecimento sócio-cultural, ou ainda enquanto campo de militância social.

Comecemos por um depoimento de uma agente da política pública municipal de assistência social em Porto Alegre. Segundo ela, a "questão religiosa" é forte nesta área, devido ao grande crescimento de outras igrejas que não a Igreja Católica, com grandes templos principalmente nas periferias, mas também centro da cidade. Estas religiões também se voltam para a assistência social. Não se trata de um fenômeno insignificante: “é diferente uma igrejinha, que se abriu lá numa vila, e que congrega algumas pessoas, e um templo desse aí, que tu vês um número sério de pessoas, um monte de gente, saem aquelas multidões de dentro das igrejas". De outro lado, há problemas que este crescimento evidencia e suscita: de um lado, evidencia uma busca de algo pelas pessoas, que a informante só substancia em termos de as pessoas "buscarem alguma resposta para as suas aflições"; de outro lado, suscita o problema da manipulação - os grupos

13 Esta não é uma constatação que incida sobre o número de ações ou de beneficiários. Este ainda é pequeno, no que se refere às religiões minoritárias. Não o é em relação à Igreja Católica. Basta mencionar-se o universo de pessoas assistidas por suas pastorais sociais e pelas entidades caritativas mantidas por ordens religiosas ou por instâncias oficiais da Igreja. Mas, no caso das religiões minoritárias, trata-se do fato em si, indicador de que já não se trata apenas de: a) práticas exclusivamente religiosas; b) ações fundamentalmente promovidas pela Igreja Católica; c) ações recém iniciadas, podendo tratar-se de iniciativas com décadas de experiência acumulada. 
"mais fanáticos" tenderiam muito ao assistencialismo e à dinâmica de troca entre doações e bênçãos. Para ela, esta variável, tem hoje uma importância muito grande no Brasil. Uma representante da Cáritas em Porto Alegre também se coloca a este respeito, e fala na necessidade de se terem alguns cuidados, para que a religião não seja usada "como uma forma também de subordinação, como uma forma de exploração das pessoas, seja no aspecto financeiro, seja no aspecto afetivo". O destino do comentário é claro: as novas expressões de religiosidade não-católicas, que surgem "a partir de um contexto de angústia, de desespero das pessoas", cuja capacidade de resolver os problemas ou de contribuir para isto é posta é dúvida.

Um segundo aspecto que liga nossa discussão anterior sobre a cultura com esta, sobre o lugar da religião, se refere à reconhecida ênfase do discurso religioso na consolação para os males da vida cotidiana. A dimensão expressiva e lúdica da cultura aqui assume a forma de uma dimensão inspirativa, que anima e mobiliza as pessoas em torno de suas crenças, para tomadas de posição diante dos problemas vividos. Isto se soma ao potencial mobilizador de participar na vida associativa, em espaços mais coletivos ou comunitários, como igrejas, comunidades, pastorais, terreiros, quando estes estimulam "uma prática voltada ao social”, como diz nossa informante da Cáritas. Neste caso, o pertencimento religioso

contribui para que essas pessoas resgatem a sua própria identidade, enquanto pessoa, que não é um objeto de favor, mas que é sujeito de direitos, que é um ser capaz e de possibilidades; então, à medida que a Igreja, que as religiões conseguem contribuir, isso é fundamental para a inclusão.

A observação cotidiana, neste caso e em vários outros depoimentos nas três cidades cobertas pela pesquisa, aponta para a diferença que tal participação fez na vida de muitas pessoas, levando mesmo à formação de novas lideranças sociais. Mais uma vez, como no parágrafo acima, o limite estaria na possibilidade de "acomodar as pessoas" por meio de ações meramente assistencialistas. Mas na medida em que invista em formação, na "libertação das pessoas como sujeitos", a religião pode contribuir para motivar mudanças.

Além de inspirar e mobilizar, a religião ilustra uma outra função insistentemente reservada à cultura nos discursos governamentais ou da sociedade civil: "resgatar" ou elevar a auto-estima das pessoas; libertá-las do sentimento de culpa por sua própria condição de pobreza e se valorizarem como sujeitos, propondo um caminho de mudança. Isto demanda um trabalho em nível micro, um trabalho de base, fundado na interação face-a-face, que as 
igrejas ${ }^{14}$ podem ajudar a fazer. Outro efeito desta função é, nas palavras de uma gestora do Programa Cheque Cidadão, do governo do estado do Rio de Janeiro (1999-2006), o de ajudar a pessoa a se reerguer e deixar de depender do benefício governamental. Ao desenvolver a auto-estima, a religião criaria um senso de valor próprio que desestimularia a dependência. Isto também se aplicaria aos voluntários religiosos, que passariam para os beneficiários, este senso de dignidade e auto-determinação que favoreceria a eficiência do programa ao inspirar confiabilidade e cuidado nos beneficiários.

Como as questões de cultura e identidade podem ser encontradas ou trabalhadas no contexto de instituições religiosas? Uma primeira indicação é dada por uma representante da Igreja Metodista em Porto Alegre. Para ela, trabalhar estas questões demandaria um marco organizacional diferenciado, para além do espaço eclesial: entidades educacionais e entidades de ação social (abrigos, lares, creches, etc.), com corpo técnico qualificado (fala de cientistas sociais). Mesmo assim, não é tão fácil. Para a informante, as instituições educacionais têm mais facilidade de colocar estas questões do que as assistenciais. Pois além do marco organizacional, há questões referentes à mentalidade de quem executa $\mathrm{O}$ trabalho. Ela exemplifica:

quando se construiu um projeto político-pedagógico numa creche, aqui em Porto Alegre, buscando então todas essas noções de valorização do indivíduo, de protagonismo infantil, enfim, de todas as funções mais modernas de solidariedade, enfim de um indivíduo-cidadão mesmo, de resgatar essa cidadania tanto de crianças quanto de suas famílias, a gente encontrou bastante dificuldade, porque os funcionários, por exemplo, quase não conseguiam discutir essas questões; estão tão desabituados que são... às vezes têm pouca instrução de ensino, e se colocam às vezes um pouco como uma barreira a ser a renovação.

Nas igrejas (metodistas), estas discussões são ainda mais difíceis de se fazer, mesmo quando os pastores as assumem. Houve muitos embates, por exemplo, em função da adoção do Plano de Vida e Missão da Igreja Metodista brasileira, em 1982, que explicitamente assumia a ação social transformadora como parte dos objetivos da Igreja, e gerou divisões ou a recusa de aplicá-lo nas comunidades eclesiais locais.

É possível ainda colocar a questão em termos do espaço em que convivem diferentes religiões e do desafio colocado hoje pela pluralidade religiosa crescente do país. Um informante ligado à Agenda Social, já apresentada acima, comentou a respeito em relação à

14 Boa parte das falas desliza recorrentemente de "religiões" para "igrejas", o que indica de que posição se fala: a das igrejas cristãs, com as possíveis novidades de que se assume a pluralidade interna do campo cristão brasileiro e de que, por vezes, esta postura representa uma tomada de posição ecumênica. Compreensível do ponto de vista demográfico - mais de $80 \%$ dos brasileiros são cristãos - esta ambigüidade só desaparece em algumas falas laicas e nas falas dos representantes de religiões não-cristãs. 
presença da religião nas favelas. Para começar, estas foram historicamente um espaço de presença das religiões afro-brasileiras. A Igreja Católica, desde a primeira metade do século $\mathrm{XX}$, iniciou um trabalho nas favelas, que teve uma marca de tolerância em relação inclusive ao duplo pertencimento de fiéis ${ }^{15}$. Mais recentemente, um fator novo veio interromper esta convivência pacífica: o crescimento evangélico nas favelas, principalmente de igrejas pentecostais e neo-pentecostais, que assumem uma posição de aberto confronto com as religiões afro-brasileiras, levando a um certo "esvaziamento", "diluição das manifestações afro-brasileiras".

Isto estaria trazendo um impacto, segundo esta ótica, sobre a identidade cultural das comunidades faveladas, que se reflete, por exemplo, na deslegitimação do samba, uma marca muito forte da cultura da favela. As escolas de samba das favelas perdem participantes locais e precisam recorrer crescentemente a pessoas de fora, o que contribui para diluir a identidade cultural originária. Introduz-se ainda uma mudança comportamental, na medida em que a sociabilidade, o lazer, a produção cultural tradicionais nas favelas são confrontadas por uma proposta religiosa mais limitadora da dimensão nãoreligiosa da vida cotidiana ${ }^{16}$. Esta postura menos tolerante em relação à religiosidade não implica numa rejeição da proposta da Agenda Social, contudo. O informante reconhece, e nisto é confirmado por outra representante da Agenda, em entrevista distinta e espontaneamente, que há um grande número de participantes que são evangélicos principalmente de igrejas "mais abertas”, que já estariam há muito tempo nas favelas, e não fariam parte das estratégias de confronto assumidas pelas neopentecostais; cita as igrejas batistas e da Assembléia de Deus. Não se trata, portanto, de uma fronteira que divida categoricamente religião e não-religião, ou evangélicos e não-evangélicos, mas formas distintas de prática religiosa em sua relação com elementos da cultura negra brasileira.

15 Nosso informante ressalta que, desde a segunda metade dos anos de 1970, a Pastoral de Favelas da Igreja Católica foi um espaço de articulação e proteção de militantes resistentes à ditadura e dos movimentos sociais - "foi o grande guarda-chuva do movimento social no final dos anos setenta". Ela atuava em contraposição à própria posição do Arcebispo Eugênio Sales, embora, no início dos anos de 1980, tenha perdido espaço, pois não realizava evangelização, mas ação política. Mas teve um papel fundamental na organização do movimento de favelas no Rio de Janeiro, numa direção que se opunha aos partidários da ditadura.

16 A rigor, uma variável que nosso informante não leva em conta é a medida em que tem havido uma reelaboração cultural, por parte da cultura gospel, dos elementos profanos e religiosos da cultura afro-brasileira. O pagode, o samba e mesmo o funk têm suas versões gospel, com grande difusão de mídia e indústria cultural (criação de gravadoras e editoras, vendas em supermercados e lojas de discos e vídeos, realização de grandes shows, formação de um público jovem consumidor entre os evangélicos). Neste sentido, não estão morrendo, estão mudando de conteúdo, num processo de mudança cultural que apresenta todas as ambigüidades de qualquer outro: a ameaça a formas mais tradicionais de expressão, a disputa por adesão com propostas similares, confrontos e escaramuças culturais e políticas por hegemonia). 
$\mathrm{Na}$ intervenção da Agenda Social, este informante ressalta a preocupação metodológica de

não se deixar "contaminar" por uma ou outra religião, para que eles percebam que primeiro, religião tem que ter o seu lugar, e a minha posição é que, na sociedade, cada um tenha o seu lugar, mas tem que ser assim num campo particular de cada grupamento. Quando você discute questões mais amplas como é, por exemplo, ah, sei lá, a urbanização de uma favela ou o enfrentamento com o próprio poder público, você tem que sair desse campo e tentar ver o bem comum. O bem comum tem passado por várias orientações religiosas.

Este entendimento procura dar espaço para que os atores religiosos, ao participar de ações da sociedade civil, compareçam com suas identidades particulares, mas, ao mesmo tempo, espera daqueles que "encontrem seu lugar" num projeto mais amplo que os inclui, mas não lhes pertence exclusivamente, que possui outros participantes, outros procedimentos, com os quais se tem que atuar. Tal prática também aparece, como já vimos em seção anterior, no caso do Viva Rio.

Uma questão importante suscitada pela dinâmica do reconhecimento se refere a como o poder público pode atuar ou até onde se envolver na garantia de espaço público à emergência das minorias religiosas. Tome-se o caso das religiões afro-brasileiras. Em Porto Alegre, a questão se colocou tanto na área de educação - nos conteúdos curriculares sobre cultura e história afro-brasileira - quanto no apoio dado à Semana da Umbanda, e na criação de um espaço, no parque Saint-Hillaire, para celebrações religiosas afro-brasileiras ${ }^{17}$. No caso da Semana da Umbanda, grupos ligados a esta religião procuraram a prefeitura para solicitar apoio: material de divulgação, montagem de palco, carro de som. Um gestor municipal argumentou que, diante desta demanda, o poder público não pode se declarar neutro, simplesmente; este

entende que [a umbanda] é uma religião estigmatizada, que é uma religião que já sofreu todo esse estigma e a gente sabe que é um direito da população afro-brasileira ou afrodescendente, minimamente uma questão de reparação, de ter reparado toda essa carga de dívida histórica que a gente sabe, que a gente conhece. Então, disponibiliza, como também disponibiliza se vierem os luteranos, se vierem os da Assembléia de Deus, enfim. É um pouco isso assim, [o poder público] não toma partido, mas ele apóia, dá suporte, dá possibilidade.

No Rio de Janeiro, coloca-se a experiência dos Governos Garotinho e Rosinha Matheus. O elemento mais visível aqui é o da utilização das redes de comunidades religiosas, especialmente igrejas evangélicas, como intermediárias da implementação das políticas de transferência de renda do governo estadual, não só a mais famosa - e

17 Cf. Eu assumo minha negritude. Declare sua auto-estima, sua raça/etnia. Porto Alegre, Secretaria Municipal de Direitos Humanos e Segurança Urbana, 2004, p. 12-13. 
controversa -, o Cheque Cidadão, mas também as similares que, a partir deste, foram adotadas: o Cheque-Saúde-Cidadão, para portadores de hanseníase e tuberculose; o Cheque-Escola, para famílias com crianças em idade escolar; o Cheque-Rural, para apoiar agricultores na entresafra, ou pescadores, na época de defeso; o Cheque da Terceira Idade; o Cheque-Portador-de-Deficiência - sendo que, à exceção do cheque-saúde e do chequerural, os demais também eram distribuídos por entidades religiosas. A lógica de recorrer a esta modalidade de parceria é a da capilaridade desse tipo de instituições no que se refere aos chamados bolsões de pobreza ${ }^{18}$ e a de sua não-politização (em contraste com as associações de moradores e mesmo muitas ONGs) e não-envolvimento com a criminalidade (novamente, são citadas as associações de moradores) ${ }^{19}$. Apesar da pecha difundida de que o Cheque Cidadão era uma forma de instrumentalização dos evangélicos, o programa, tanto no texto da lei que o criou, como no rol de entidades que se habilitaram a implementá-lo, abria-se a qualquer forma de organização religiosa e incluía instituições evangélicas, católicas, espíritas e uma sinagoga. Em 1999, quando foi criado, o programa habilitou 500 entidades voluntárias, que distribuíam, cada uma, 100 cheques. Esta primeira leva foi formada por entidades convidadas. A partir daí, passou-se a avaliar propostas de outras entidades, em número maior do que o de recursos a serem distribuídos.

O Programa Cheque Cidadão proibia qualquer exigência de contrapartida das famílias beneficiadas (cobrança de dízimos ou ofertas), de participação em cerimônias religiosas ou vinculação às comunidades religiosas como condição para recebimento do cheque, exigia que se cadastrassem as pessoas mais pobres na comunidade (o que também implicava em que não podiam residir fora dela). Esta última exigência partia do princípio de que a entidade voluntária deve acompanhar as famílias, verificando o atendimento das condições

18 Esta capilaridade se distribuiria desigualmente entre as religiões. Responsáveis pelo Programa destacaram, comentando a proporção de igrejas/entidades evangélicas em comparação com igrejas/entidades católicas, que estas últimas se fixam nas áreas mais centrais, mesmo nos bairros pobres e, portanto, não chegam tão próximo dos pobres como as comunidades evangélicas. Depois haveria as dificuldades da estrutura centralizada da Igreja Católica, para credenciar uma nova paróquia ou entidade, contrastando com a agilidade das igrejas evangélicas, que, assim, reuniriam as exigências com maior rapidez.

19 Uma justificativa adicional aventada por uma informante responsável pelo Programa é a expectativa de que a convicção religiosa do voluntário, que estaria prestando contas diante de Deus por seus atos, daria maior confiança ao poder público: "Eu acho que essa questão do cunho religioso, de você ter das pessoas que trabalham em entidades religiosas, que são representantes, saber que existe uma pessoa que está lá em cima, que está vendo o que está acontecendo, que o que ele fizer, ele vai pagar por isso, enfim, eu acho que a questão da religião, de você lidar com pessoas que tenham compromisso religioso antes de tudo te dá um certo conforto de que 'Poxa! O cara que prega a palavra, que prega o bem... eu não acredito que vai haver algum problema, um problema mais grave, se a gente continuar com a entidade religiosa sendo a distribuidora do benefício'." O surpreendente, neste comentário, é que trata-se de uma justificativa oferecida por um agente do estado, que, embora laico, contaria com os preciosos préstimos de uma espécie de "auditor divino" para as ações dos agentes religiosos! 
exigidas para a qualificação destas, o que só é possível se houver proximidade física entre agentes implementadores e beneficiários.

As entidades religiosas passam a ser, na expressão de uma das coordenadoras do Programa em 2005, “extensão do Palácio [do governo, JAB]”, “agentes públicos delegados" e precisam atender a certas exigências do poder público: espaço físico adequado à distribuição dos cheques, CNPJ como entidade religiosa, visita in loco de técnicos do governo estadual, voluntários responsáveis devidamente credenciados. Por outro lado, o poder público autorizava a realização, no ato mensal de entrega dos cheques, de cerimômias cívico-religiosas em que se poderiam fazer orações de agradecimento (pela provisão estatal!!) e outras atividades de conscientização dos beneficiários:

A gente pede não que se faça um culto, mas que se faça um evento ecumênico, onde se agradece a Deus, se agradece ao Governo do Estado, por exemplo, pelo benefício, o porquê do benefício, qual é o valor que o Cheque-cidadão tem, o valor que ele tem que ter para a família. Então se faz uma palestra...

Falando espontaneamente sobre as razões do momento de agradecimento mensal, a informante comenta:

o agradecimento, eu acho que é até para você despertar o sentimento de agradecer, de que existe uma pessoa acima. Aquilo que eu te falei, muito difícil você ver alguém que é ateu, que não acredita. E quando a gente encontra uma pessoa que é ateu, ele não se sente ultrajado porque (...) a gente está agradecendo a um Deus aquele benefício. E a gente quer, na verdade, despertar o lado... o lado que a pessoa tem de espiritual. Eu acho que o que falta muito nas pessoas - e a gente vê isso, e que a gente vê também que uma religião faz você ficar mais coeso - é isso: é a falta de espiritualidade; então isso leva a mais violência, a você não respeitar.

Por outro lado, admitidamente, a implementação do Programa produziu um efeito de reforçar a identidade ou a prática religiosa de muitos beneficiários, pelo fato de verem sua religião envolvida numa ação de cunho social ou por terem que ir à igreja (os exemplos citados são de católicos e evangélicos), (re)aproximando-os mais dela. Assim, intencionalmente ou não, a ação pública estaria promovendo a difusão religiosa, ainda que não de uma ou outra religião em particular, mas daquelas envolvidas com o Programa.

O questionamento não pode ser de princípio, pelo simples fato de haver uma implicação mútua entre atores religiosos e o poder público. O laicismo nestas circunstâncias torna-se muito mais uma marcação de posição do que uma alternativa factível. Um depoimento de liderança do Viva Rio, portanto, no mesmo contexto espacial do controvertido Programa Cheque Cidadão, reforça esta questão da importância desta vinculação, por meio de um diagnóstico relativo à representatividade social destes setores: 
Eu acho que símbolos religiosos, espiritualidade, têm peso no Brasil. Não a instituição religiosa; tanto quanto a cultura religiosa, têm muito peso e vive um momento de transformações muito grandes. A maior delas, eu acho que é provocada pelo mundo evangélico, e sem dúvida tem muita repercussão. Na nossa prática, no Viva Rio, diante da crise da violência e da fragilização das associações de moradores, que são associações civis, representativas, eleitas, com estatutos e etc., é mais comum. $\mathrm{Na}$ maioria dos projetos, você encontra interlocutores muito mais confiáveis, consistentes e tal, no mundo religioso do que no mundo civil. O mundo civil está dominado. (...) Então, o templo religioso fica um pouco à parte disso, se preserva, em grande medida. E aí há toda uma sonoridade, organização, quadros, discursos, posturas, etc., que dão muito mais solidez àquelas organizações religiosas do que às organizações civis - nas favelas, sem dúvida. Então, qualquer favela, em qualquer situação, sempre que há uma interlocução, é preciso procurar os religiosos do lugar."

Olhando-se de baixo para cima, a participação de atores religiosos em projetos com vistas a enfrentar a fragilização da sociedade civil pela violência, pelo crime organizado e pelas disputas partidárias no interior das associações comunitárias, tornar-se-ia imprescindível.

Outro aspecto desta mesma questão é o dos embates entre evangélicos e afrobrasileiros e o quanto de intervenção o estado deve fazer. Aqui se coloca o debate sobre a intolerância religiosa e até onde deve haver neutralidade do estado. Novamente tomando o exemplo de Porto Alegre, um representante da Secretaria de Direitos Humanos e Segurança Urbana, que atuava, então, na promoção de políticas afirmativas para afrodescendentes argumenta que travava-se um debate na Secretaria sobre o assunto. Para ele, a Secretaria

não trabalha a questão religiosa diretamente, mas como trabalha com a questão racial, mesmo que a gente saiba, claro, que nem todo negro é de origem africana, mas a gente entende ela a questão das religiões africanas - como uma questão da cosmovisão africana. Uma questão de identidade, uma questão de resistência. Então, é nesse sentido, não na questão do ritual, ou coisa parecida. É uma questão mais sociológica do que teológica - não sei se é a palavra correta.

O espinhoso desta distinção é que ela não está dada como uma evidência. Trata-se antes de uma tomada de posição, uma tentativa de demarcação de uma fronteira, que legitime uma intervenção do estado sem que ela seja predicada sobre uma escolha religiosa. "A gente entende" que as religiões africanas são uma "questão sociológica" e que há negros que não têm "origem africana": como entender este raciocínio? Primeiramente, como uma tomada de posição ético-política, não como uma constatação sociológica ao abrigo da disputa: mesmo que $\mathrm{x}$, entendemos y. A controvérsia está tipificada e um lado é escolhido. Segundo, os negros que não são de origem africana é provavelmente uma alusão aos negros evangélicos, pentecostais, por uma associação clássica que liga protestantismo a uma cultura anglo-saxã e que, aqui, parece ser ampliada para o pentecostalismo. 
Esta é uma perspectiva também encontrada entre organizações da sociedade civil que operam numa lógica laica. O AfroReggae, no Rio de Janeiro, poderia ser citado. Segundo uma de suas lideranças, a questão da religião afro-brasileira é pensada no mesmo contexto da questão cultural. Neste sentido, lamenta-se o afastamento dos terreiros, da religiosidade afro-brasileira, do centro do Rio, e o seu quase desaparecimento em boa parte das favelas próximas do centro da cidade, passando a concentrarem-se na Baixada Fluminense. Isto seria um efeito do avanço das igrejas pentecostais. Tal discussão, contudo, não é feita "necessariamente do ponto de vista religioso, porque a religião, cada um escolhe a sua, mas a gente faz do ponto de vista cultural, de que todas as religiões devem ter o direito de se afirmar e ter seu espaço. E de que os preconceitos que se associam, por exemplo, às religiões afro-brasileiras com o demonismo, com o satanismo, devem ser combatidos." Isto seria uma necessidade, não somente diante dos adversários, das forças promotoras do preconceito e da discriminação, mas também na perspectiva de o trabalho ser melhor compreendido pelos próprios beneficiários, crianças e jovens que, em muitos casos, são evangélicos, e cujos pais reagem diante de oficinas de percussão e outras formas da cultura negra brasileira:

a gente busca em algum momento um diálogo com as famílias para que se entenda que aquilo que a gente faz primeiro não é algo profano, não tem nada a ver com religião. Mas segundo, também, que a religião não é necessariamente aquilo que eles pensam que é a religião afro-brasileira.

Assim como no caso da política pública de promoção da cultura afro-brasileira se procura distinguir o religioso do cultural, mesmo quando trabalhando explicitamente o tema e os conteúdos religiosos do candomblé ou da umbanda, no caso do AfroReggae, fazse uso da simbologia da religiosidade afro-brasileira, numa reinterpretação laica da mesma. Por exemplo, numa letra de música em que se propõe uma fusão de Ogum com Xangô, para ressaltar a "questão guerreira, do trabalho" e a "questão da justiça, da luta pela justiça". Uma lógica semelhante foi utilizada no lançamento do Viva Rio, em 1993, com a utilização de uma perspectiva laica para a mobilização de uma linguagem mística da oração, da vigília, do silêncio meditativo, inscrita numa ação de caráter cívico-político de enfrentamento da violência. Recurso que tem sido repetido em ações posteriores, como em protestos subseqüentes pelas vítimas da violência ou na Campanha do Desarmamento durante o plebiscito sobre uso de armas em 2005 (cf. Leite, 2003; Conrado, 2006; 2005). 


\section{CONCLUSÃO}

Procuramos neste trabalho apresentar uma teia de caminhos, experiências e formas de cruzamento que se colocam hoje no campo das ações voltadas para enfrentar a herança de desigualdade e opressão que a história brasileira lega aos atores contemporâneos, governamentais e da sociedade civil. Nosso argumento principal foi o de que a percepção da complexidade da exclusão social tem levado a uma dupla reelaboração do tema da cultura: enquanto forma de produzir uma representação alternativa dos excluídos como pessoas com valor e dignidade intrínsecos, como sujeitos de direito, e como forma de dar lugar a formas de organização coletiva que não se regulam apenas pela identidade da privação material ou da posição subalternizada “em geral”. Esta reelaboração é contestada, disputada de muitas maneiras. Não indica um processo unidirecional, não possui um único sujeito, não envolve os mesmos atores em todo lugar, não chega sempre aos mesmos resultados. Por mais que a vivência cotidiana destas experiências procure ressaltar o caráter coesivo da cultura, sua tendência a produzir identidade num sentido comunitarista, é impossível não perceber as disputas hegemônicas que se travam através de e em torno da cultura. Elas envolvem distintos campos de ação - como a esfera estatal ou a dinâmica mais fluida dos projetos governamentais no poder, a esfera da sociedade civil (por si plural e contraditória, mais nomeando um projeto do que descrevendo um lugar) - e dão lugar à movimentação de diferentes atores (como atores institucionais e grupos informais, atores laicos e atores religiosos, atores corporativistas e atores "republicanistas").

Parte integrante deste contexto, à parte considerações de ordem estatística ou de representatividade numérica, refere-se à atuação de entidades de caráter religioso, em articulação com agências governamentais ou da sociedade civil, ou interpeladas por estas a tomarem posição sobre questões sociais e referentes ao manejo das diferenças culturais no Brasil contemporâneo. Trata-se de um campo de ações incrementais, tentativas, sujeitas a arranjos contingentes, mas associáveis seja às ênfases recentes na revisão da forma e conteúdo das políticas sociais e na ampliação dos espaços públicos associada à idéia de que a diferença cultural se inscreve como uma questão de justiça tanto quanto de “enriquecimento" da vida cívica. Neste processo parece que todos são aprendizes, embora não se possa simplesmente descontar que certas entradas ao tema estão eivadas de inconsistências político-ideológicas e concessões a tendências internacionais que longe de representarem modelos, são outras tantas formas de intervir politicamente no campo também nelas o lugar da religião se apresenta por vezes como algo a ser reconhecido de 
forma irresistível. Procuramos aqui explorar algumas formas de materialização desses diálogos de fronteira.

\section{REFERENCIAS}

BARTOLOMEI, Maria Luisa. Universalismo y diversidad cultural en America Latina, El Otro Derecho, vol. 7, no. 2, 1995

BIRMAN, Patrícia. Imagens religiosas e projetos para o futuro. IN: BIRMAN, Patrícia (org.). Religião e Espaço Público. Rio de Janeiro, Attar, 2003, pp. 235-55

Movimentos cívico-religiosos no Rio de Janeiro e alguns de seus impasses: o caso do Mural da Dor. In: BIRMAN, Patrícia e LEITE, Márcia Pereira (orgs.). Um Mural para a Dor. movimentos cívico-religiosos por justiça e paz. Porto Alegre, UFRGS, 2004, pp. 221-86

; LEITE, Márcia Pereira (orgs.). Um Mural para a Dor. movimentos cívico-religiosos por justiça e paz. Porto Alegre, UFRGS, 2004

BRIDGES, Thomas. The Culture of Citizenship: Inventing Postmodern Civic Culture. Albany, SUNY, 1994 (Disponível em http://www.civsoc.com/index.html)

BURITY, Joanildo A. Radical religion and the constitution of new political actors in Brazil: the experience of the 1980s. Tese de doutorado em ciência política. Colchester, Essex University, mimeo., 1994

Identidade e Política no Campo Religioso: estudos sobre cultura, pluralismo e o novo ativismo eclesial. Recife, UFPE/IPESPE, 1997

Identidade e cidadania: a cultura cívica no contexto de uma nova relação entre sociedade civil, indivíduos e Estado, Cadernos de Estudos Sociais, vol. 15, nº. 2, 1999, pp. 223-253

Cultura e Cultura Política: sobre retornos e retrocessos, Revista de Ciências Sociais (UFC), vol.33, no. 1, 2002, pp.7-31

Redes, cultura e religião nas politicas sociais. Relatório final. Recife, Fundação Joaquim Nabuco, 2007, mimeo.

Organizações religiosas e ações sociais: entre as políticas públicas e a sociedade civil, Anthropológicas, v. 18, $\mathrm{n}^{\circ}$. 1, 2008, pp.7-48

CASANOVA, José. Religion, the new millennium, and globalization (2000 Presidential Address), Sociology of Religion, inverno de 2001. Disponível em http://findarticles.com/p/articles/mi m0SOR/ is 4 62/ai 82477973. Acesso em 10/5/2005

CASTELLS, Manuel. The Power of Identity (The Information Age: Economy, Society and Culture, vol. 2). London: Blackwell, 1997

CONRADO, Flávio César dos Santos. Ação Social Evangélica: Projetos Sociais. Regiões metropolitanas de Belo Horizonte, Rio de Janeiro e Campinas. Rio de Janeiro, ISER, 2005

Religião e cultura cívica: Um estudo sobre modalidades, oposições e complementaridades presentes nas ações sociais evangélicas no Brasil, 2006. Tese (Doutorado em Antropologia). PPGA/UFRJ, 2006

HAYNES, Jeff. Transnational religious actors and international politics, Third World Quarterly, vol. 22, no. 2, 2001

INGLIS, Christine. Multiculturalism: New Policy Responses to Diversity (MOST Policy Paper Series $\mathrm{n}^{\circ}$. 4). MOST/UNESCO, 1996. Disponível em http://www.unesco.org/most/pp4.htm. Acesso em $5 / 5 / 1998$ 
KOENIG, Matthias. Democratic Governance in Multicultural Societies: social conditions for the implementation of international human rights through multicultural policies (MOST Discussion Paper Series $\mathrm{n}^{\circ}$. 30). MOST/UNESCO, 1999. Disponível em http://www.unesco.org/most/ln2pol2.htm. Acesso em 10/6/2000

KYMLICKA, Will. Ciudadanía Multicultural. Una Teoría liberal de los derechos de las minorías. Barcelona/Buenos Aires/México, Paidos, 1996

e NORMAN, Wayne. El retorno del ciudadano. Una revisión de la producción reciente en teoría de la ciudadanía, Agora, no. 7, Invierno 1997, pp. 5-42

LEITE, Márcia Pereira. Novas relações entre identidade religiosa e participação política no Rio de Janeiro hoje: o caso do Movimento Popular de Favelas. In: BIRMAN, Patrícia (org.). Religião e espaço público. São Paulo, Attar, 2003, pp. 63-95

. As mães em movimento. In: BIRMAN, Patrícia; LEITE, Márcia Pereira (orgs.). Um Mural para a Dor: movimentos cívico-religiosos por justiça e paz. Porto Alegre, UFRGS, 2004, pp. 141-189 MOUFFE, Chantal. The Return of the Political. London, Verso, 1996

The Democratic Paradox. London, Verso, 2000

1992

(ed.). Dimensions of Radical Democracy: Pluralism, Citizenship, Community. London, Verso,

PAREKH, Bhikhu. Dilemmas of a multicultural theory of citizenship, Constellations, vol. 4, n. 1, 1997

PREMDAS, Ralph R. Public policy and ethnic conflict (Discussion Paper Series, $\mathrm{n}^{\circ}$ 12). MOST/UNESCO, 1997. Disponível em http://www.unesco.org/most/premdas.htm. Acesso em $15 / 8 / 1998$

PROGRAMA das Nações Unidas para o Desenvolvimento - PNUD. Relatório do Desenvolvimento Humano 2004: Liberdade Cultural num Mundo Diversificado. New York, Pnud, 2004

SENNA, 2006

SODRÉ, Muniz. Claros e Escuros: Identidade, povo e mídia no Brasil. Petrópolis, Vozes, 1999

TOURAINE, Alain.. Crítica da Modernidade. Petrópolis, Vozes, 1994

Poderemos viver juntos? Iguais e diferentes. Petrópolis: Vozes, 1999

UNESCO Brasilia Office. Convenção sobre a Proteção e Promoção da Diversidade das Expressões Culturais. Paris, 20/10/2005. Disponível em http://portal.unesco.org/en/ev.phpURL ID=31038\&URL DO=DO TOPIC\&URL SECTION=201.html. Acesso em 20/4/2006

VITAL, Christina; CUNHA, Marilena. www.vivafavela.com.br, Comunicações do ISER, ano 22, no. 58, 2003, pp. 11-41 